\title{
Relation between Climate and Soil Productivity in the Tropics
}

\author{
M. V. K. Sivakumar \\ ICRISAT \\ Niamey, Niger
}
A. Manu
Texas A\&M University
College Station, Texas

\author{
S. M. Virmani \\ ICRISAT \\ Patancheru, India \\ E. T. Kanemasu \\ University of Georgia \\ Georgia Station, Georgia
}

There is a heightened concern about producing sufficient food for the current increase in world population. Two alternatives for boosting food production are to increase yield per unit area or expand agriculture into new areas. On a short-term basis, the second alternative seems more attractive. Wortman and Cummings (1978) quote Food and Agriculture Organization (FAO) data that indicate the global availability of 1.6 billion ha of potentially arable land, most of which is in the tropics.

Divergent statements about tropical climates are found in the literature because of the lack of a clear definition of the characteristics and variability of these climates in relation to agricultural applications. Many misconceptions stem from the fact that the tropical climates range from extreme deserts to evergreen forests. Soil is the medium in which the plant expresses its response to climate at a given location. Climate is one of the active factors and generally the dominant one, although its effect is modified by other factors to give rise to a variety of individual soils in any given climatic region (Brengle, 1982). Essentially, climate and soils are linked together inextricably to determine what can be potentially exploited in a given region.

Copyright (C) 1992 Soil Science Society of America and American Society of Agronomy, 677 S. Segoe Rd., Madison, WI 53711, USA. Myths and Science of Soils of the Tropics. SSSA Special Publication no. 29. 
Numerous examples abound in literature that show clearly different cropping possibilities under the same climatic regime because of differences in the soil types under consideration. Similarly, the potential of the same soil type is expressed differently under different climatic regimes. Given the extent of coverage of tropics, it is beyond the scope of this chapter to give an exhaustive treatment of the subject. We have drawn upon several examples to illustrate different points.

\section{CHARACTERISTICS OF THE TROPICS}

One of the basic myths arises in the definition of the tropical region itself. In the simplest system of climatic classification, many elements of which were derived from the ancient Greeks, the tropics are regions bounded by the astronomically significant $23^{\circ} 27^{\prime}$ North and South parallels. This measurement defines only the extreme seasonal limits of the sun's vertical rays and does not consider rainfall. Hence, no modern climatic classification system accepts this as the only criterion. According to Miller (1971), "Supan delimited the tropics by the mean annual isotherm of $68^{\circ} \mathrm{F}\left(20^{\circ} \mathrm{C}\right)$; actually $70^{\circ} \mathrm{F}\left(21^{\circ} \mathrm{C}\right)$ may be a better limit. Koppen (1931), in defining the tropical belt as having 12 mo above $68^{\circ} \mathrm{F}$, accepted the temperature of the coldest months as the boundary criterion. Later he preferred the isotherm of $64^{\circ} \mathrm{F}$ $\left(18^{\circ} \mathrm{C}\right)$, which runs close to mean annual isotherm of $70^{\circ} \mathrm{F}$.

Another major myth of the tropics is that crops can be grown throughout the year since temperatures are seldom too low for plant growth. While it is true that crops requiring considerable heat to mature and ripen can be grown at any time of the year, this is possible only if there is sufficient moisture. Thus, rainfall variability can be a major factor determining the vegetation types. Based on rainfall, the tropics have been divided mainly into three zones: arid, semiarid, and humid. The limits used for the exact delineation of these zones has been a subject that has attracted much attention. Therefore, several climatic classifications exist in literature, based on precipitation (Koppen, 1936), precipitation and temperature (de Martonne, 1926; Emberger, 1955), precipitation and evaporation (Thornthwaite, 1948; Troll, 1965), and moisture availability period (Hargreaves, 1971). For our purpose, however, we have chosen to treat the subject of climate and soil productivity with reference to arid, semiarid, and humid tropics.

\section{CHARACTERISTICS OF CLIMATE RELATED TO SOIL PRODUCTIVITY}

Several climatic factors are related to soil productivity. It is possible to show correlations with rainfall for several different soil characteristics. 


\section{Rainfall}

In temperate regions, temperature is a major factor in cropping. In the tropics, however, rainfall is the major climatic factor affecting soil productivity. It determines the state of vegetation and the surface water as well as groundwater. It has been established that a definite relationship exists between rainfall and the physical and chemical characteristics of the soil.

\section{Rainfall Pattern}

One general myth of the tropics is that rainfall here is generally more abundant, and hence less limiting, than in the temperate regions. One argument in support of this assertion is that annual precipitation in South America (which contains large regions with tropical humid climates) is $1350 \mathrm{~mm}$ while North America has an annual precipitation of only $670 \mathrm{~mm}$ (Trewartha, 1968). While in absolute terms this is true, the rainfall patterns in tropics are more variable and undependable. Variability is a major concern, but it is primarily the deviations that adversely affect the agricultural production. In regions such as the Sahel, the magnitude and extent of the rainfall deviations is very large. As Bowden (1979) described, no growing season is or will be nearly the same in precipitation amount, kind, or range as the previous growing season. Rainfall is best characterized by its irregularity as can be seen from the annual rainfall variation at Filingue, Niger for the past $84 \mathrm{yr}$ (Fig. 6-1a) which varies from 284 (1984) to $980 \mathrm{~mm}$ (1912). In the Sahelian and Sudanian climatic zones of West Africa, below-normal rainfall could persist for 10 to $20 \mathrm{yr}$ as can be seen from 1969 to 1988 in the case of Filingue.

Coefficient of variation (CV) of annual rainfall in the arid and semiarid tropics is 20 to $30 \%$ while in the humid tropics it is usually about 10 to $20 \%$. In the humid tropics, negative departures in annual rainfall from the mean still leave actual totals that are in most cases sufficient to support reasonable crop growth and yield (Fig. 6-1b). It is the large positive departures that create conditions of excess moisture detrimental to the crops in the humid tropics.

There is a myth about the humid tropics that water is never a limiting factor in this region. Although humid tropics show lower $\mathrm{CV}$ for annual rainfall than the semiarid tropics, rainfall in some months is usually less variable in the semiarid regions than in the humid regions. Lawson and Sivakumar (1989) showed that CV for July and August rainfall is much less at the semiarid Ouagadougou, Burkina Faso than in Ibadan, Nigeria located in the humid tropics.

One of the less commonly understood features of rainfall in the arid and semiarid regions is the high spatial variability. Spatial variations in rainfall are easily discernible in the field from the uneven distribution of plant cover. In the tropics, especially in Africa, raingauge placement is so widely dispersed that it makes it difficult to assess meaningfully the spatial variations of rainfall on a regional scale. However, microscale studies in the tropics clearly highlight the problem of spatial variability. On a $2.5-\mathrm{km}^{2}$ area at the 

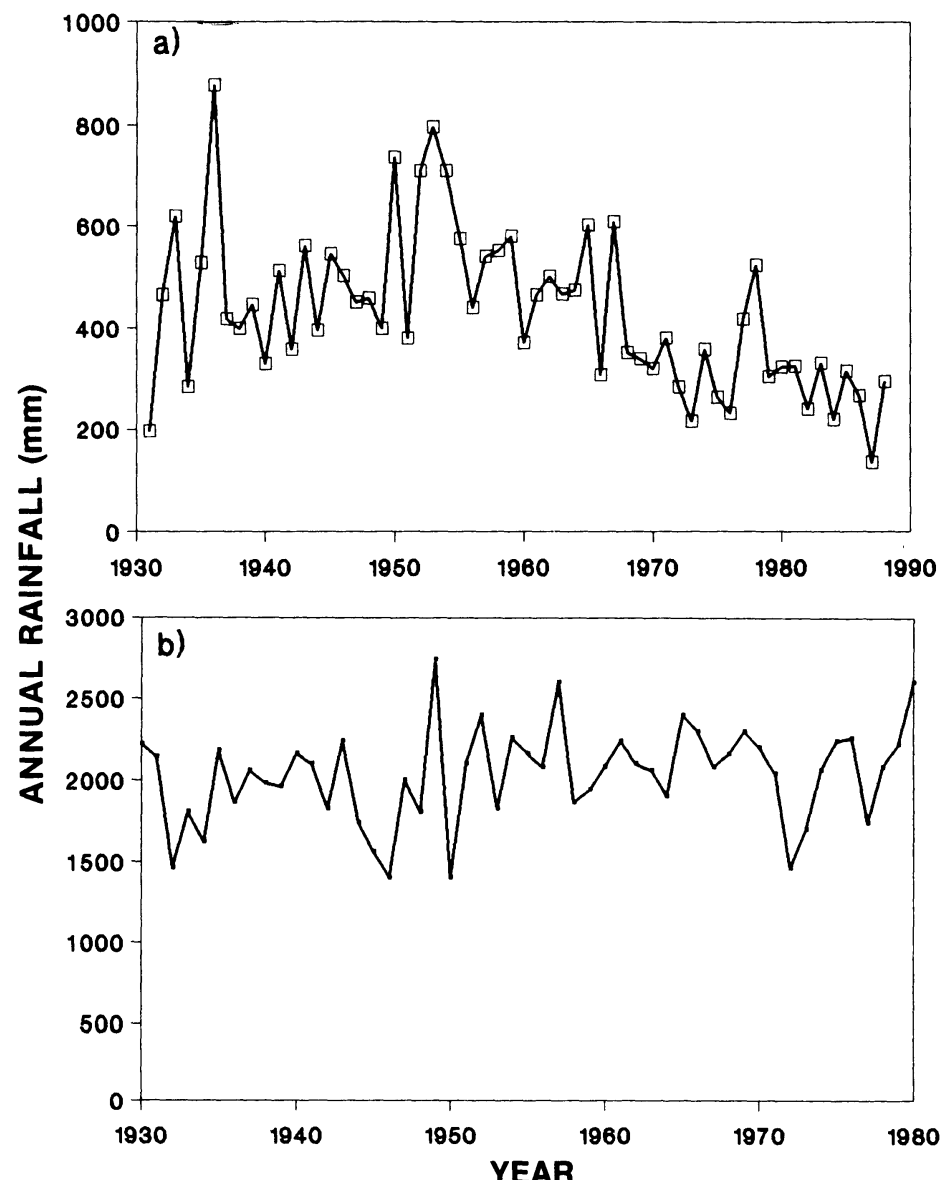

Fig. 6-1. Annual rainfall variation at (a) Filingue, Niger and (b) Benin City, Nigeria.

ICRISAT Sahelian Center, Sadore, Niger, the spatial variability of rainfall was studied using 18 raingages and the extremely high variability in individual storms is shown in Fig. 6-2. Sivakumar and Hatfield (1989) showed that even for seasonal total rainfall, spatial variability persists. This could partially explain the observed variability in plant stands for crops planted on the same day in different fields on the same soil type.

In the tropics, two predominant rainfall patterns, monomodal and bimodal, are observed. In the Southern Sahelian and Sudanian climatic zones of West Africa, rainfall patterns are pronouncedly monomodal. In regions closer to the equator, bimodal rainfall patterns are more common, as in Kenya and parts of Southern India. It is interesting to note that the CV of rainfall in July and August is much higher in the humid bimodal region of Nigeria than in the monomodal rainfall regions of Niger and Burkina Faso (Lawson \& Sivakumar, 1989). This could lead a myth that monomodal rainfall patterns are perhaps more desirable than the bimodal patterns since drought spells are less likely under the monomodal regimes because of concentration of rainfall in a single rainy season. Even under the monomomdal rainfall 
25.7 15.8

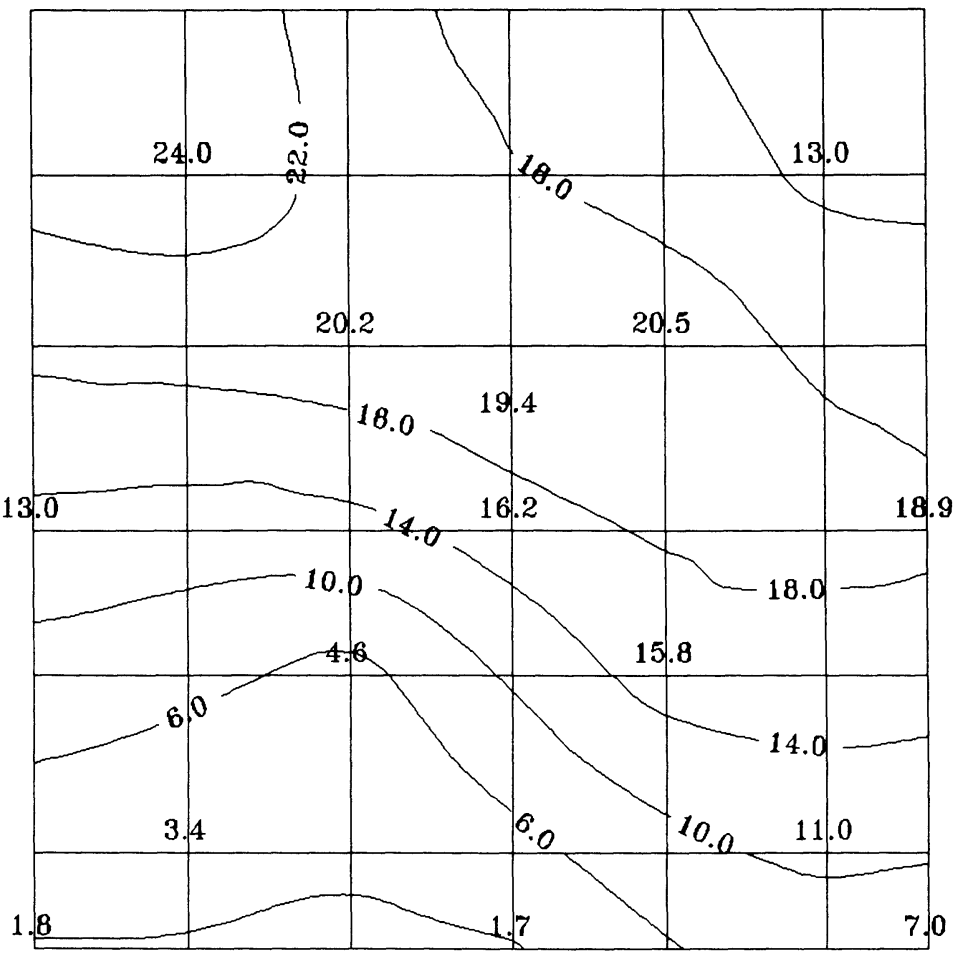

Fig. 6-2. Spatial variability of rainfall on 24 Aug. 1989 at ICRISAT Sahelian Center, Sadore, Niger.

regime, the onset of rains is quite variable as shown in a recent analysis of daily rainfall data in the semiarid regions of West Africa (Sivakumar, 1988). For example, at Niamey, Niger the onset of rains is quite variable and the standard deviation of the onset of rains is $17 \mathrm{~d}$.

Since the ending of rains in the Sahelian and Sudanian climatic zones is sharp and less variable, rainy period is usually shorter in years with delayed onset of rains. In view of the short growing season and the farmer's limited capacity in terms of available power, the number of days available prior to the optimum date of sowing is an important issue. On the sandy soils of the Sahel, evaporation rates are generally high immediately following a rain (Wallace et al., 1988). On such soils, the efficiency with which sowing can be completed before the water evaporates is a critical factor. Hence, the productivity of the soils in this region is significantly influenced by these rainfall events.

\section{Rainfall Intensities and Erosion}

Rainfall erosivity is much higher in the tropics than in the temperate regions. Calculations of rainfall erosivity for West Africa by Roose (1977) show that rainfall erosivity factor for the Ivory Coast ranged from 500 to 1400 in contrast to 150 to 650 reported from USA (Wischmeier \& Smith, 1960). While only 5 to $10 \%$ of the temperate storms are erosive, most of 
the tropical storms are considered erosive because of the high intensity (Lal, 1977). For example, $82 \mathrm{~mm}$ or one-seventh of the seasonal normal rainfall was received in just under $3 \mathrm{~h}$ on 4 Aug. 1985 at the ICRISAT Sahelian Center (ISC).

The energy supplied by a storm is determined by the intensity and duration of rainfall. In northern Nigeria, individual rainstorms of $>50 \mathrm{~mm}$ with peak intensities of 120 to $160 \mathrm{~mm} / \mathrm{h}$ are not uncommon (Kowal \& Kassam, 1977) and peak intensities of more than $250 \mathrm{~mm} / \mathrm{h}$ for short periods were reported (Kowal, 1970). Peak values of up to $300 \mathrm{~mm} / \mathrm{h}$ at Niono, Mali (Hoogmoed, 1981) and $386 \mathrm{~mm} / \mathrm{h}$ at Niamey, Niger (Hoogmoed, 1986) have also been observed.

In the humid tropics, a wide range of rainfall intensities are reported, but higher intensities are mainly associated with thunderstorms (Lal et al., 1980). At Morningside, Tanzania, average rainfall intensity for all months during the year exceeded $20 \mathrm{~mm} / \mathrm{h}$ while in the rainiest month of April, average intensity exceeded $80 \mathrm{~mm} / \mathrm{h}$ (Constantinesco, 1976). Peak values in excess of $150 \mathrm{~mm} / \mathrm{h}$ sustained over $30 \mathrm{~min}$ have been observed at Ibadan, Nigeria.

Raindrop impact is a significant factor influencing soil erosion and formation of surface soil crust. During an intense rainstorm, large rain drops break soil aggregates, disperse fine soil particles, and fill surface voids thus effectively sealing the soil surface and reducing the water intake rate (Cannell \& Weeks, 1979). The absence of factors able to recreate an aggregated structure, as for instance freezing and thawing do under many temperate soils, means that the deterioration is more or less permanent, unless the soil is put under fallow vegetation for an extended period (Greenland, 1977).

Studies on drop size distribution in Samaru, Nigeria (Kowal \& Kassam, 1977) showed that in contrast to the temperate and subtropical regions, brief rainstorms in the tropics are composed of much larger drops. Perrier (1987) reported that during a typical convective storm in the Sahel, wind-driven raindrops striking a dry bare soil surface under the force of a squall or storm front can have an intensity of about $1000 \mathrm{~mm} / \mathrm{h}$ for a short period where raindrops are driven downward at a velocity of about $60 \mathrm{~cm} / \mathrm{s}$. Estimates by Kowal and Kassam (1977) from Nigeria suggest an average kinetic energy load of $34.6 \mathrm{~J} /\left(\mathrm{m}^{2} \mathrm{~mm}^{1}\right)$. Calculations of Finkel (1986a) showed that the falling rain drops generate 576 times as much power as the equivalent amount of water flowing over land. This force is absorbed by the soil surface and falling raindrops break down and disperse the soil aggregates; cause compaction and sealing of soil surface. Medium-textured soils whose silt content is high are most subject to dispersion in water and form the thickest crusts (Brengle, 1982).

Falling raindrops decrease the infiltration capacity of the topsoil in two ways: (i) by compressing later as they strike the soil surface and plugging the soil pores with loosened soil particles, and (ii) by seepage downwards into the soil of moving soil grains (WMO, 1983). Rates of infiltration are affected by soil types, especially when there are problems of soil crusting. On the bare, weakly crusted soil surface of the sandy soils at ISC, infiltra- 
tion rates of up to $100 \mathrm{~mm} / \mathrm{h}$ have been reported (ICRISAT, 1984). However, clogging of soil pores by crusting can reduce the infiltration rate by 2000 times the initial infiltration rate (McIntyre, 1958; Wischmeier \& Smith, 1958).

Under conditions of high rainfall intensities, runoff and soil loss are quite common. Data compiled from different studies in West Africa (Table 6-1) show that runoff and soil loss vary with location. Cropped soils, as one would expect, showed much lower rates of runoff.

During the process of runoff, raindrops falling on the layer of water flowing down-slope cause turbulence in this water layer, which assists the soil particles to remain suspended. Even gravel with a diameter of up to 1 $\mathrm{cm}$ can be transported by such a turbulent water layer (WMO, 1983).

In areas situated in the low-lying plains that fan out from a range of mountains, runoff from the heavy seasonal rainfall in the mountains causes flash floods. These floods cause extensive damage to soils and crops, while erosion on the mountains and the fan slopes causes deep gullies (Constantinesco, 1976).

Erosion studies conducted at Samaru by Kowal (1970) and Kowal and Stockinger (1973) showed that serious erosion hazards result in a decline in soil fertility and cause problems of soil and water management that are largely unknown in the temperate and subtropical climates. At Niangoloko, Burkina Faso, it has been observed that the increase in water erosion from 1.4 $\mathrm{t} /$ (ha yr) to $13 \mathrm{t} /$ (ha yr) decreased the yield of millet from $729 \mathrm{~kg} / \mathrm{ha}$ to 352 $\mathrm{kg} / \mathrm{ha}$ (FAO, 1977b).

In the humid tropics, clearing the forest for cultivation results in a larger stream flow. At Mbeye in Tanzania, long-term average increases in stream flow of the order of $50 \%$ have been recorded compared with the forested control (Edwards \& Blackie, 1975). In Kenya, a 51-mm storm in 30 min caused a loss of nearly $3500 \mathrm{~m}^{3}$ of soil from a 10-ha coffee (Coffea arabica L.) field with a slope of $8^{\circ}$.

An increase in rainfall does not necessarily result in an increase in the erosion. Soil texture and structure both influence the erosion processes of detachment and transport. Clay particles are more difficult to detach than sand due to their attractive charges, but are easier to transport once they are dislodged (Cannell \& Weeks, 1979). There are other important intervening factors such as soil erodibility, land form (slope, steepness, and shape), and management systems (Lal, 1980).

Landslides can also be initiated by intense rainstorms in mountain areas and could cause extensive damage.

\section{Potential Evapotranspiration}

Potential evapotranspiration (PET) or water demand in the arid and semiarid zones is usually high due to the consistently high air temperatures and radiation load (Jackson, 1977). On the other hand, rainfall is erratic. When rainfall exceeds PET, soil moisture reserves are recharged. When rainfall is less than PE, soil moisture reserves are used. In arid and semiarid areas, $\mathrm{PE}$ generally exceeds rainfall. At semiarid locations such as Niamey, Ou- 


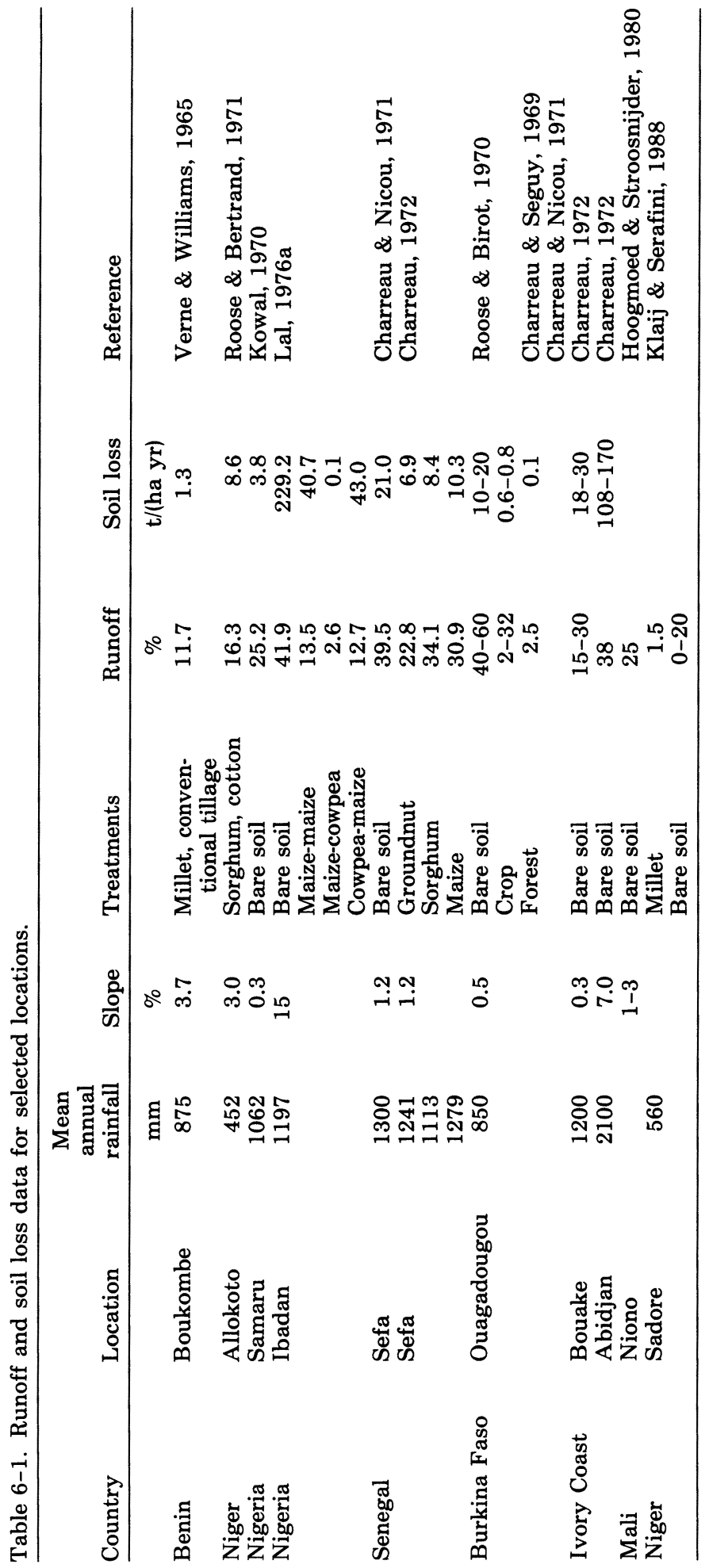


agadougou, and Hyderabad, rainfall exceeds PE for only 2 to 3 mo (Fig. 6-3). Ibadan, Nigeria, although in humid tropics, shows a 1-mo period in the rainy season when rainfall is less than PE (Fig. 6-3).

The classical work of Denmead and Shaw (1962) showed that the relationship between soil moisture content and transpiration varied with the evaporative demand. On a clear, dry day when the potential evaporation was as high as 6 to $7 \mathrm{~mm} / \mathrm{d}$, the decline in transpiration occurred at a very low soil moisture tension. On a heavily overcast day with an evaporative demand of 1 to $4 \mathrm{~mm} / \mathrm{d}$, transpiration rate did not decline until the soil moisture reached $120 \mathrm{~J} \mathrm{~kg}^{-1}$, not much above the permanent wilting point. The erratic rainfall distribution and unpredictable droughts in the arid and semiarid tropics create conditions of high evaporation demand even in the middle of the rainy season and crops could be exposed to considerable stress.

\section{Relationship Between Rainfall and Soil Moisture Storage}

One of the myths of tropics is that since rainfall is abundant, practically any crop can be grown. The precipitation actually stored in the soil depends upon the soil type, surface conditions, and moisture status. Holmes (1961) showed that moisture depletion from a given soil varies with the soil type. The soil profile serves as means of balancing, over time, the discontinuous water supply with a continuous atmospheric evaporative demand (Russell, 1980), which eventually affects plant growth. Because of the great diversity in texture, structure, type of clay, organic matter content and depth of tropical soils, the available water in the soil varies greatly. Weekly soil moisture storage calculations for four soil types of Hyderabad region in India (Fig. 6-4) demonstrate this clearly. In shallow Alfisols, there is little soil moisture storage over extended drought periods. In deep Alfisols, medium deep Vertisols, and in deep Vertisols, there is a fair degree of moisture storage for a substantially longer time during the growing season compared with the shallow Alfisols. Thus, under identical rainfall conditions, the effects of shortterm intraseasonal droughts on crop moisture status will differ on different soil types. Therefore, rainfall alone is not an adequate guide to agricultural potential. It is necessary to work out the soil water balance and select crops that grow and mature in the short periods of favorable soil water regime.

\section{Length of the Growing Season}

From the above discussion, it should be apparent that the length of growing season, which is a balance between the water supply and demand, varies depending upon the rainfall and the soil type, particularly its moisture-holding characteristics. Calculations of the length of the growing season for three soil types at Hyderabad (Table 6-2) show that on shallow Alfisols with a low moisture-holding capacity, the available growing season is much shorter than on deep Vertisols. This would mean that long duration crops have a higher probability of success on the deep Vertisols than on the shallow Alfisols. 

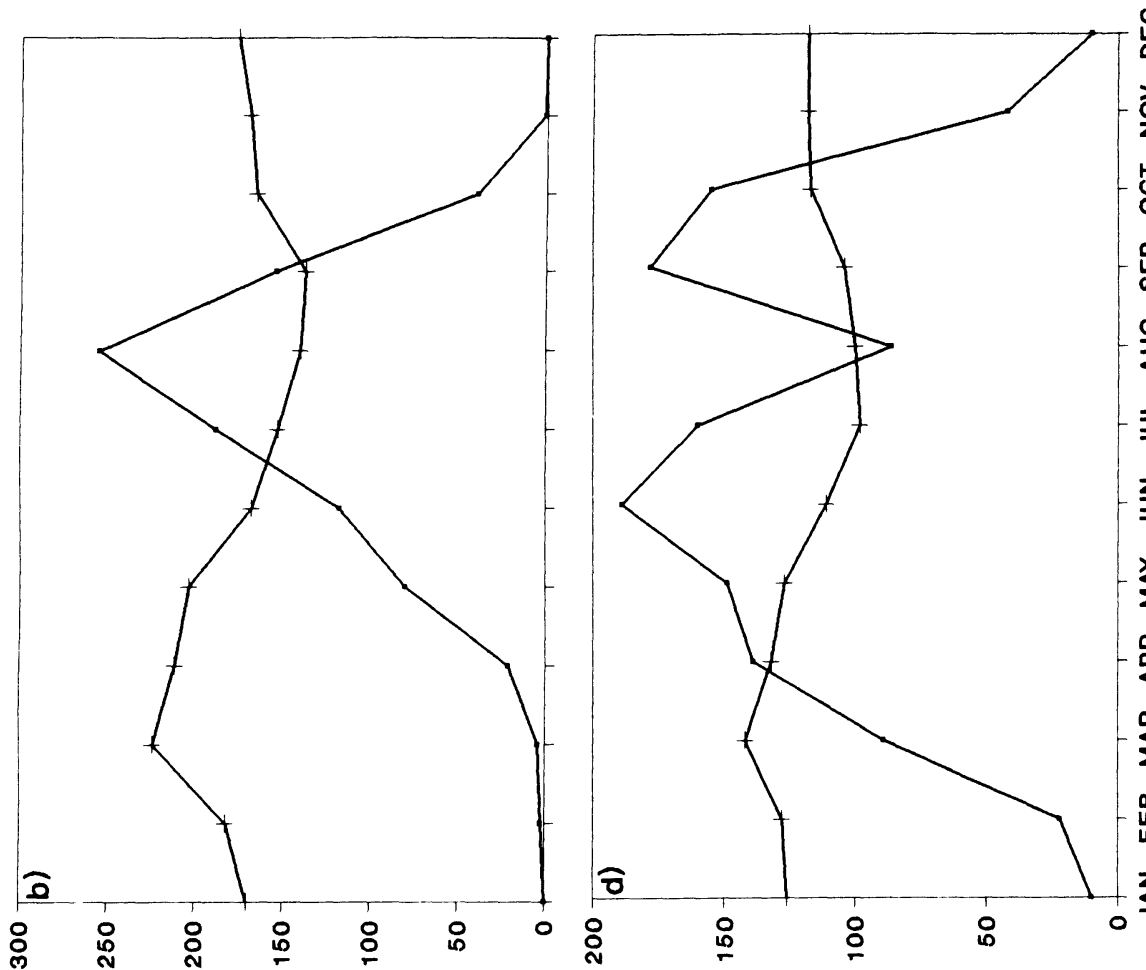

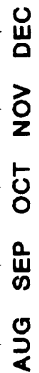

5
ว
$z$
z

文

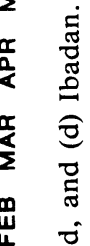

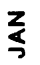

준

유 \&
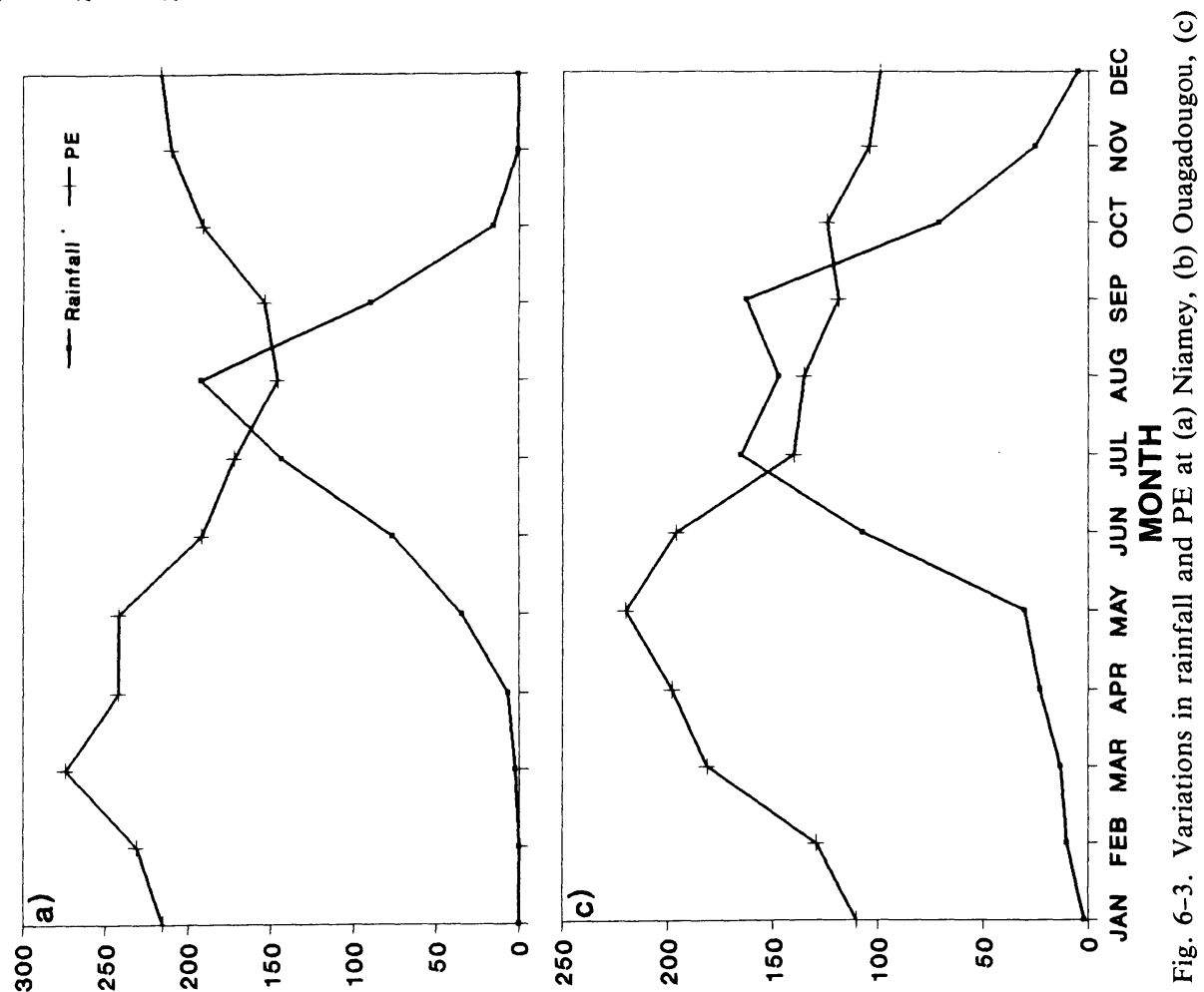

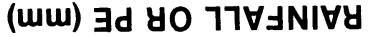




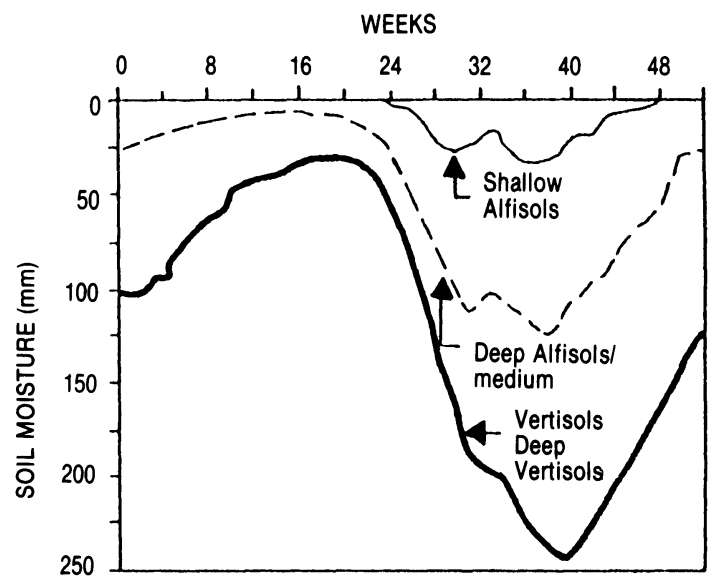

Fig. 6-4. Weekly soil-moisture storage in three soils (based on Hyderabad data, 1901-1970). Source: Virmani (1980).

\section{Drought and Soil Moisture Availability}

Droughts in the arid and semiarid tropics are set off by rainfall deviations that fall far below the average rainfall which is already low and undependable. Length of the dry spells that are likely to occur during the growing season can be calculated from historical rainfall data (Sivakumar, 1991). In the Southern Sahelian and Sudanian climatic zones of West Africa, dry spells are most likely to occur in the early and later parts of the growing season. The soil type and its water-holding characteristics play an important role here since droughts early in the growing season occur after the long dry season. The capacity of the soil to retain water, even from small rain showers, thus become critical. On the light, sandy soils that show significantly high evaporation rates immediately after a rain (Wallace et al., 1988), these early season droughts can lead to crop mortality and force the farmers to resow their crops.

When droughts occur during the grain-filling stage, antecedent soil moisture condition is critical to sustain crop growth and productivity. Hence on soils with a higher water-holding capacity, crops can withstand the drought for a much longer period.

Table 6-2. Length of the growing season (in weeks) $†$ for three soil conditions. $\ddagger$ Source: Virmani (1980).

\begin{tabular}{lccc}
\hline & \multicolumn{3}{c}{ Available water-storage capacity } \\
\cline { 2 - 4 } Rainfall probability & Low & Medium & High \\
Mean & $50 \mathrm{~mm}$ & $150 \mathrm{~mm}$ & $300 \mathrm{~mm}$ \\
$75 \%$ & 18 & 21 & 26 \\
$25 \%$ & 15 & 19 & 23 \\
\hline
\end{tabular}

$\dagger$ From seed-germinating rains (25 June) to the end of season (time when profile moisture reduces $\mathrm{AE} / \mathrm{PE}$ to 0.5 ).

$\ddagger$ Low: shallow Alfisol; Medium: shallow to medium-deep Vertisols; High: deep Vertisol. 
In the bimodal rainfall areas of semiarid regions of India, dry spells of varying lengths impose a restriction on the crop choice. In regions where the intervening dry spell is longer than $1 \mathrm{mo}$, two distinct rainy periods are recognized (southwest monsoon from June to September and northeast monsoon in October to November) but exploitation of these periods depends largely on the soil type. On deep Vertisols with higher water-holding capacity, a long duration legume crop is intercropped with a short duration cereal so that the cereal crop is harvested in the main southwest monsoon season and the legume continues through the shorter northeast monsoon season. The shallow Vertisols are generally left fallow in the southwest monsoon season and are cropped on residual moisture in the northeast monsoon season.

In the Savannah region of West Africa, long dry spells result in sparse vegetation. When this vegetation is completely removed through uncontrolled grazing, and slashing and burning, it leads to a hardened soil surface. Consequently, it sets off the process of long-time soil degradation.

\section{Waterlogging and Leaching}

When water in the soil surface due to rainfall, runoff, or irrigation is in excess of the rate of infiltration, and when the topography is enclosed or very flat, temporary waterlogging of the surface or leaching (if the soil horizons are permeable) could occur. Although factors such as topography, physical characteristics of the soil, and influence of soil use by people play an important role in promoting waterlogging, alternating seasons of wet and dry periods could create conditions conducive to waterlogging. In the humid tropics, leaching of clay colloid fractions consisting of clay mineral and $\mathrm{Fe}$ and $\mathrm{Al}$ hydroxides from the upper horizons leads to acidification. Percolation of these fractions through the profile produces morphological and physicochemical changes. When waterlogging and leaching are particularly pronounced, imbalances may occur in the functioning of the soil and these may sometimes be big enough to be termed degradation (FAO, 1977b).

The evolution of soils such as gleysols, planosols, histosols, and partly vertisols is influenced by waterlogging.

\section{Salinization and Alkalinization}

The level of groundwater and its chemical composition are essential factors influencing salinization and soil degradation (WMO, 1983). Groundwater level at a particular location is linked to local climatic conditions. In the arid regions where rainfall is much less than evaporation, salts in solution are drawn upwards by capillary action leading to the formation of saline soils. Also, the salt spreads after the humid years (Kelley, 1963). Weathering of rocks containing sodic minerals causes accumulation of salts on the spot or is transported into low-lying areas. Extensive saline soils around the Lake Chad area is a good example (Cheverry, 1974).

In the semiarid and subhumid tropics, clay leaching and accumulation further down the profile results in the formation of solonetz that quickly causes the development of hydromorphy (WMO, 1983). 


\section{Temperature}

The importance of temperature in influencing soil productivity in the tropics can be related to von't Hoff's temperature rule that states that for every $10^{\circ} \mathrm{C}$ rise in temperature, the velocity of chemical reaction increases by a factor of two to three. The deep-weathered mantle of the tropical regions could be related to the extreme physical and chemical weathering of parent material promoted by high rainfall and temperature. This reflects in the relatively high clay contents, increased aggregation and favorable soil structure in the humid tropics as compared to the sandy structure, poor aggregation, and structure associated with the semiarid soils.

There is an intimate relationship between rainfall incidence and air temperature patterns in the tropics. There is a myth that temperature is not limiting to crop growth in the tropics. However, high temperatures can have a detrimental effect on crop growth in many tropical regions. In the arid and semiarid regions where the onset of the rainy season is preceded by a long dry season, environmental conditions during the stage of crop establishment are usually harsh. From the analysis of frequency distribution of air temperatures in West Africa, Sivakumar (1987) showed that mean maximum temperatures could exceed $40^{\circ} \mathrm{C}$ at the time of sowing and that absolute temperatures could be much higher. Although one or two showers can fulfill the moisture requirement for sowing, on the sandy soils of the Sahel, the soil moisture evaporates quickly and if a period of dry, clear weather follows, the soil surface temperatures rise rapidly up to $55^{\circ} \mathrm{C}$. Under these conditions, seedling death is quite common leading to plant stands much below the recommended 10000 hills/ha.

On soils prone to crusting, such as the Alfisols, crust formation is hastened by high soil temperatures and the additional heat of wetting when raindrops strike a dry soil surface (Perrier, 1987). As the soil gets wetter, the thermal conductivity of the sandy soils of the Sahel was shown to have increased to as much as $0.005 \mathrm{cal} /(\mathrm{cm} \mathrm{s})$ per ${ }^{\circ} \mathrm{C}$.

Even in the humid tropics, seedling growth of soybean [Glycine max (L.) Merr.], cowpea [Vigna unguiculata (L.)], and pigeonpea [Cajunus cajan (L.)] has been shown to be adversely affected by soil temperatures exceeding $34^{\circ} \mathrm{C}$; threshold value for maize (Zea mays L.) was $30^{\circ} \mathrm{C}$ (Lal, 1974).

In the humid tropics, rapid deforestation for human settlement and cultivation is posing problems. In the southern states of Nigeria, Lowe (1974) reported that 8000 ha were cleared annually. This figure was expected to rise to 60000 ha by 1984. Dense vegetation removed for human settlement and cultivation in the humid tropics leaves the soil exposed to solar radiation causing the soil temperature to rise. Under conditions of high soil temperatures, the organic matter in the soil decreases rapidly through decomposition. It also limits soil microfauna and microbial activity (Jenkinson \& Ayanaba, 1977; Lal, 1987). 


\section{Wind}

Wind as a climatic factor has a significant effect on the soil productivity in the tropics. A popular myth is to associate damaging effects of wind with tropical cyclones, that are common in the coastal areas. Strong winds are capable of causing extensive mechanical injury and desiccation anywhere.

Particularly dangerous to the environment is blowing dust accompanied by the erosion of the topsoil. Wind erosion is catastrophic in the semiarid tropics where a shift in the ecological balance has led to creation of conditions that accentuate wind erosion. Acute food shortages resulting from increased population pressures and drought have led to the use of marginal lands, overgrazing, and removal of trees and shrubs. Using the desertification map of the world, Balba (1980) estimated that about 577 million ha in the world were vulnerable to desertification due to sand movement. The area of very high desertification due to sand movement was about 44 million ha, 15 million ha in the arid zone, and 29 million ha in the semiarid zone.

Wind erosion is not a problem if a continual wet soil surface or lack of strong winds prevails (WMO, 1983). This is more frequent in the arid, treeless regions with sudden fluctuations in weather and an active wind regime, leading to degradation of the soil cover. Soils of most semiarid lands developed under grass on relatively flat topography. The protective grass cover was removed for cropping and under conditions of severe drought, the soil became exposed to wind erosion. In the Sahelian zone, rains are preceded by violent winds that can remove $10 \mathrm{~cm}$ or more of unprotected soil from the field in a few hours that leads to the exposure of highly acidic and sometimes impermeable subsoil.

The main feature of the wind regimes in the Sudanian and Sahelian climatic zones of West Africa is the distinction between the dry and wet seasons (Davy et al., 1976). During the dry season, the harmattan winds blow from the desert areas northeast of the region. In the rainy season, the monsoon regime brings humid winds from the Atlantic Ocean and equatorial Africa to the Southwest.

Surface wind speed and its duration are major factors in the formation of dust storms and the magnitude of dust flow increases with the cube of the wind speed (WMO, 1983). Average wind speeds during the dry season are generally higher, but record wind speeds for the year are expected during thunderstorms early in the rainy season. Wind speeds exceeding $100 \mathrm{~km} / \mathrm{h}$ have been recorded at ISC. Kowal and Kassam (1978) reported maximum speeds of $110 \mathrm{~km} / \mathrm{h}$ at Samaru, Nigeria. Wind velocity accompanying a storm influences its kinetic energy and hence the erosive capacity (Lal, 1977). According to Lyles et al. (1969), soil detachment is much higher at higher wind speeds and hence wind-driven rain is more effective in clod breaking. In the Sahelian zone, an enormous amount of dust from the bare, loose, sandy soils is carried in the air because of high wind speeds (Fig. 6-5). This thunderstorm type of dust-raising mechanism is connected with the systematic ascent of air in the convective currents of a storm cloud. A wall of dust several hundred meters high is frequently raised along the thundery squall line. Dur- 


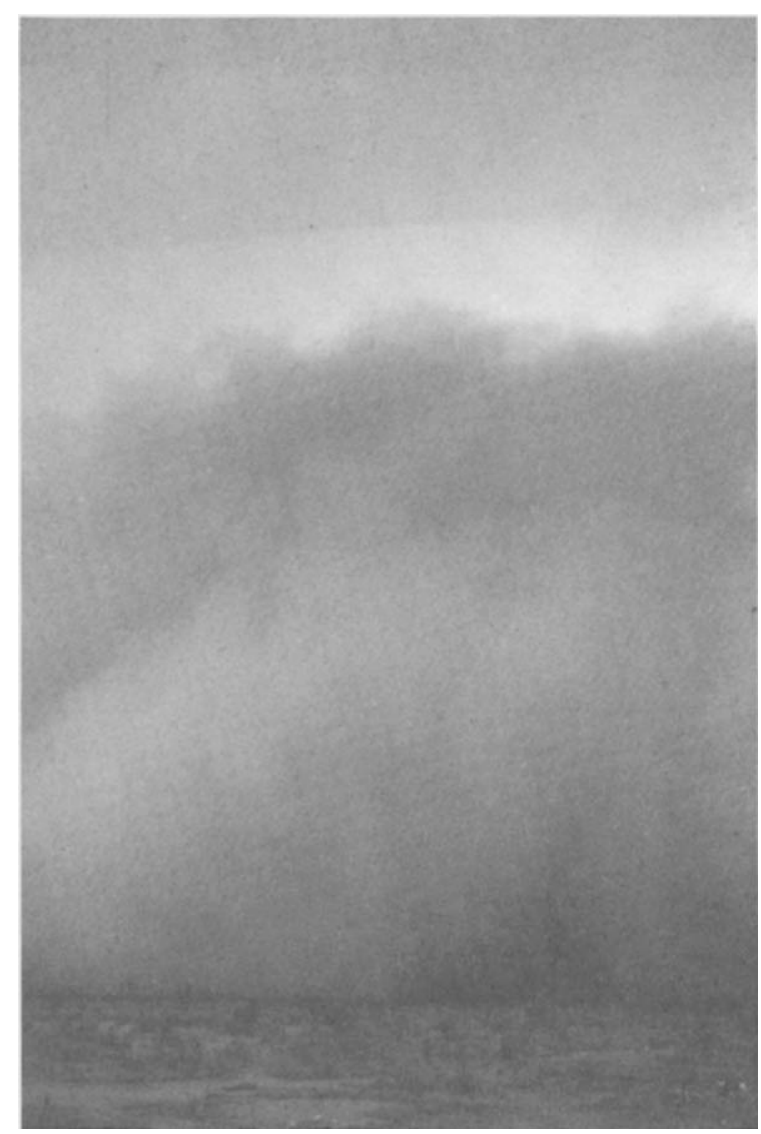

Fig. 6-5. Dust storms ahead of rains in the beginning of the growing season are common in the Sahel.

ing rainfall this sand is deposited on the young millet seedlings (Fig. 6-6). The weight of the sand and high soil temperature up to $50^{\circ} \mathrm{C}$ in the sand covering the seedling are often fatal to the seedlings (Fig. 6-7) and lead to problems of crop establishment. Downes et al. (1977) established a strong correlation between damage to young vegetable crops and a factor called total kinetic effect (TKE) which is a single expression combining wind velocity, soil flux density, and time of exposure of the seedlings.

The erosive capacity of the wind is modified, among other things, by the erodibility of the soil. This is influenced by soil texture, structure, moisture, and organic matter (Finkel, 1986b). Chepil and Woodruff (1963) found that the erodibility index varies with the amount of clay. Gravelly soils lying in a thin layer over coarse gravel are particularly susceptible to erosion. Sandy and sandy loam soils are also easily prone to erosion. Soil moisture influences the erodibility of soil. Adsorbed moisture forms a film around soil particles and the cohesion between the films creates a resistance to detachment which the force of the wind has to overcome. 


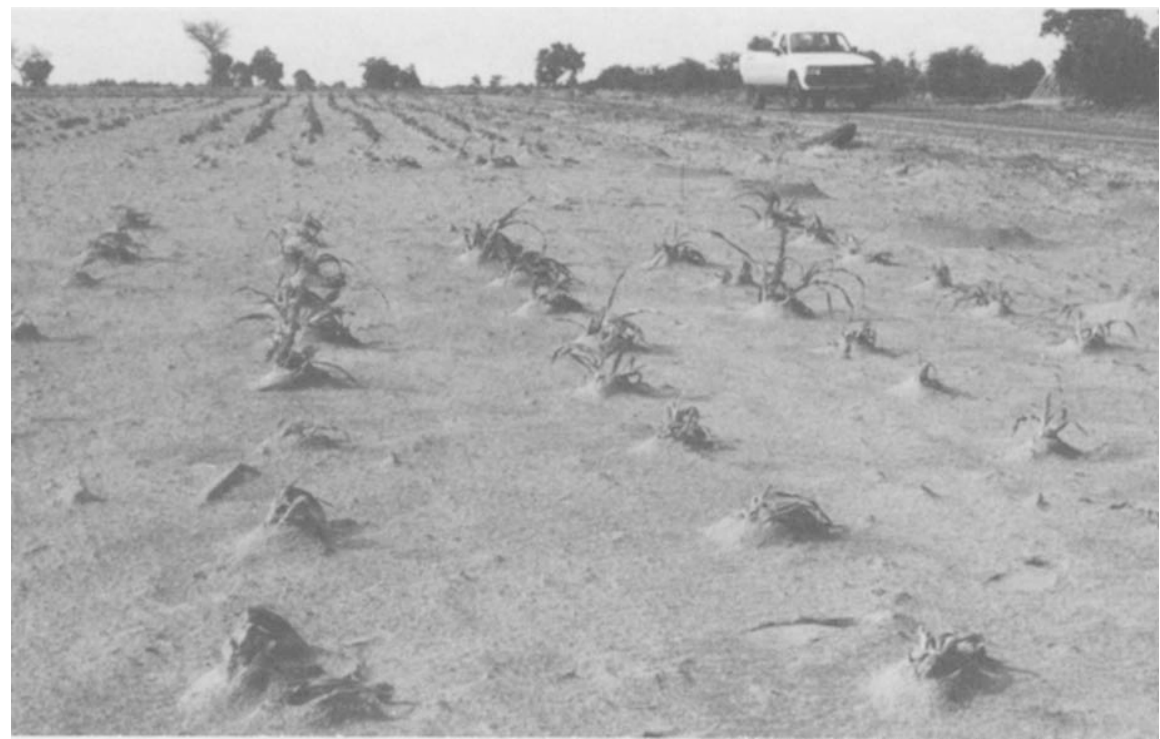

Fig. 6-6. Sand covering young millet seedlings after a dust storm.

Wind also affects soil dessication, evaporation being hastened by the removal of water vapor from the soil cavities and the soil surface. Wind action is more effective with a drier atmosphere (WMO, 1983). Wind plays an important role in the extension of saline soils and soil degradation by salinization by trapping the salt spray at the surface of the ocean.

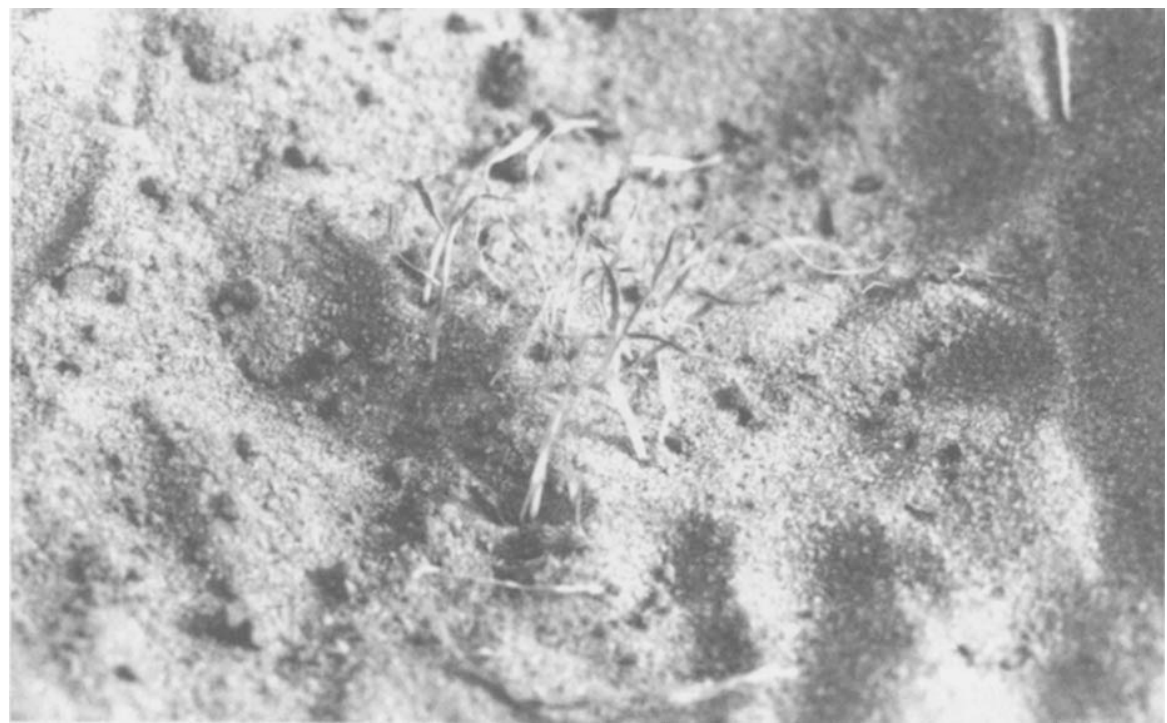

Fig. 6-7. High soil temperatures in the beginning of the growing season are fatal to the young millet seedlings. 


\section{Impact of Climatic Factors on Soil Fertility}

The implications of the climatic characteristics described earlier in the tropics to soil fertility are both direct and indirect. Increase of organic matter content with rainfall has been demonstrated by several researchers including Gavaud (1968) and Kadeba (1970). Using data from the African tropics where mean annual rainfall ranges from 350 to $1900 \mathrm{~mm}$, Jones (1973) obtained the following relationship between organic $C$ content of soil (C) and rainfall $(\mathrm{R})$ :

$$
\% \mathrm{C}=0.137+0.000865 \times \mathrm{R}(\mathrm{r}=0.514)
$$

Gavaud (1968) also indicated that the $\mathrm{C} / \mathrm{N}$ ratios tend to decline with decreasing rainfall. He obtained remarkably low $\mathrm{C} / \mathrm{N}$ values at the limits of the semiarid tropics.

High rainfall regimes of the humid areas lead to high rates of leaching bases with the simultaneous appearance of $\mathrm{H}$ and $\mathrm{Al}$ ions to compensate for the reduction of bases with respect to the saturation capacity. This leaching of bases influences the soil productivity by creating acidic environment that chemically limits the rooting depth of $\mathrm{Al}$-sensitive crops. The $\mathrm{Al}$ released during this process can also influence the $\mathrm{P}$ supply. Exchangeable $\mathrm{Al}$ reacts with $\mathrm{P}$, both native and applied, thus limiting the availability of $\mathrm{P}$ to the plants.

Oxisols and Ultisols that form the bulk of the soils of the rain forest zone, although reasonably well structured with good porosity, low bulk density, and high infiltration rate under native forest vegetation, undergo rapid physical degradation when cleared and exposed to the high-intensity rain and traffic (Lal, 1981). Nutrients in these soils are concentrated in the top 20 $\mathrm{cm}$ and sheet erosion selectively removes the organic and mineral colloids and nutrient elements (Roose, 1973; Lal, 1976b). The resulting shallowness of rooting depth affects moisture availability and fertilizer-use efficiency.

Sandy soils of the semiarid tropics have high infiltration and permeability rates. These conditions permit the downward percolation of plant nutrients that leads to further impoverishment of the already infertile soils.

In the semiarid tropics, high-intensity rains promote the accelerated removal of shallow fertile topsoil. Eroded material can take one of two courses: (i) they can be totally lost through runoff and (ii) under certain circumstances they can be deposited within short distances. The consequence of the short-range deposition of material leads to spatial variability in the soil physical and chemical properties over short distances. This results in uneven crop growth, a phenomenon that is prevalent in the sandy Sahelian soils, as documented by Wendt (1986) and Pfordresher et al. (1989).

Under conditions of waterlogging in the humid tropics, excess water in the soil induces an evolution towards an anaerobic medium. Microorganisms responsible for biodegradation of organic matter in an aerobic medium are either destroyed or inhibited. In an anaerobic medium, $\mathrm{pH}$ becomes acidic due to the freeing of organic acids and dominant chemical reactions are those of reduction. 
Although the low organic $\mathrm{C}$ content in the soils of the semiarid tropics could be linked to the low production of biomass, the effect of temperature in hastening the decomposition of plant residue can be an extremely important factor in influencing organic matter equilibrium.

There is a myth that wind erosion is always disastrous. It must, however, be mentioned that wind can act as a fertility renewal factor in the semiarid tropics. Studies conducted by the TROPSOILS team in Niger have shown that incoming wind-blown dust from remote sources is richer in clay, plant nutrients, and has a high $\mathrm{pH}$. Vine (1949) also reported introduction of clayey, ferruginous dust materials into sandy soils in parts of West and East Africa.

\section{Effects of Seasonal Changes in Climate on Soil Productivity}

In semiarid regions where a strongly alternating climatic regime of wet and dry seasons occurs, the seasonal changes can influence soil productivity. For example, when dry, Vertisols shrink and crack widely so that the topsoil material can fall down these cracks. In the following rainy season, the clays swell upon wetting. Because there is extra material in the lower horizons, pressure is exerted upwards to give a micro-relief on the soil surface. The swelling and shrinkage associated with these soils has implications with regard to residue management, root development, and water management.

\section{IMPROVED UNDERSTANDING OF THE RELATIONSHIP BETWEEN CLIMATE AND SOIL USING CASE STUDIES}

\section{Sandy Soils of the Sahel}

In the Sahel, rainfall is variable and undependable. The major soils are generally sandy in texture. For example, soils of Niger are very sandy with the sand fraction usually exceeding $92 \%$. The soil reaction is slightly to strongly acidic and exchangeable $\mathrm{Al}$ can exceed $50 \%$ of the cation exchange capacity (CEC) in some of the soils. Average water-holding capacity varies, depending upon the depth, from 75 to $150 \mathrm{~mm}$. Poor fertility is a major problem on these soils. Organic matter content rarely exceeds $0.3 \%$ and CEC generally $<3.0 \mathrm{cmol}_{\mathrm{c}} / \mathrm{kg}$. Poor structural stability of these soils is a major constraint since they are susceptible to wind erosion when dry. Under traditional farming conditions, average grain yields of millet are very low, ranging from 130 to $285 \mathrm{~kg} / \mathrm{ha}$ (Spencer \& Sivakumar, 1987).

The above conditions have led to a popular myth that Sahel means most unproductive, dry sand. However, research has shown that increasing crop yields under these conditions is based largely on an improved understanding and judicious utilization of the soil and climatic resources.

From the studies on soil physical, chemical, and hydraulic properties carried out by Hoogmoed and Klaij (1989), a clear understanding of the soils at ISC and their limitations emerges as follows: 
1. The soil has a very low fertility status and a rapid decline in its productivity could occur under conditions of continuous cropping without organic or inorganic nutrient addition.

2. Infiltration and redistribution of rainfall on these soils is very rapid, and runoff losses are generally low.

3. Mechanical treatment of the soil is effective only when the soil is moist.

4. The high rates of soil evaporation, especially with rains in the beginning of the season, demand rapid land preparation for sowing and efficient methods of planting.

\section{Climatic Data Analysis for Deriving Effective Cropping Strategies}

Prediction of Rainy Season Potential. In view of the large rainfall variability, reliance on monthly and annual rainfall totals is of little value in deriving effective cropping strategies. Parameters such as the onset and ending of rains and the length of the growing season are important for decision making. From a study of these parameters, Sivakumar (1988) showed that it is possible to predict the rainy season potential in the Sahelian zone from the date of onset of rains. This is based on the finding that the onset of rains is much more variable than the ending of rains. Therefore, an early onset of rains offers the probability of a longer growing season while delayed onset results in a considerably shorter growing season. Hence, the potential of the growing season can be assessed with reference to the date of onset of rains. This is illustrated in Table 6-3 for Niamey, Niger (database 1904-1984). If the onset of rains occurs 20 d early (i.e., by 24 May) there is a $71 \%$ probability that the growing season will exceed $120 \mathrm{~d}$. On the other hand, if rains are delayed until the beginning of July, there is only little probability of the growing season exceeding $100 \mathrm{~d}$.

Analysis of the Nature of Intra-seasonal Droughts. Although the date of onset of rains provides an idea regarding the potential of the growing season, uncertainties still abound as to rainfall distribution within the growing season. The major concerns are when droughts are most likely to occur within the growing season and what the expected length of droughts would be. Long-term daily rainfall data could be analyzed to answer such questions. Sivakumar (1990a) used the specific definition of onset of rains for each year as the sowing date and computed the length of dry spells (or days until the

Table 6-3. Probabilities of growing season length exceeding specified durations for variable onset of rains for Niamey, Niger. Source: Sivakumar et al. (1990).

\begin{tabular}{lrcrr}
\hline & \multicolumn{4}{c}{ Length of growing season (d) exceeding: } \\
\cline { 2 - 5 } Date of onset of rains & 80 & 100 & 120 & 140 \\
\hline 24 May & 100 & 98 & 71 & 15 \\
2 June & 100 & 91 & 40 & 3 \\
12 June & 98 & 71 & 15 & 0 \\
22 June & 91 & 40 & 3 & 0 \\
2 July & 71 & 15 & 0 & 0 \\
\hline
\end{tabular}


next day with rainfall greater than a defined threshold value) and the percentage frequencies of dry-spell lengths. This analysis showed that in the Sahel, dry spells from the stages of emergence to panicle initiation (up to 20 $\mathrm{d}$ after sorting) and grain filling of millet (Pennisetum glaucum (L.) R. Br.] last longer than those during panicle initiation to flowering (20-60 DAS). The implication of this analysis for soil management is that conservation of soil moisture in the establishment phase of the crop is critical.

Rainfall Analysis for Preparatory Tillage. In view of the short-growing season and the farmer's limited capacity in terms of available power, the number of days available for preparatory tillage prior to the optimum date of sowing is an important issue. Hoogmoed (1986) concluded that the size of rainfall showers relevant for decision making with regard to preparatory tillage is fairly predictable, and one could calculate the total number of days available for preparatory tillage and sowing. At Niamey, Hoogmoed and Kliaj (1989) showed that the total number of workable days is 31 and the average number of plantable days does not exceed $10 \mathrm{~d}$. This analysis shows that the speed with which planting operations can be carried out is an important issue and the use of animal traction is one of the ways to ensure this.

\section{Strategies for Exploitation of Soil and Climatic Resources}

Effective Soil Tillage Methods. On the sandy soils at ISC, beneficial effects of cultivation have been mainly attributed to enhanced rooting in time and space (Klaij \& Hoogmoed, 1987). In addition, interrow cultivation during the rainy season helps in weed control and at the end of the season kills weeds and can help in saving precious soil moisture for the subsequent rainy season crop.

Ridging and planting millet on the ridges have been shown to improve the seedling survival compared to the conventional flat planting (Kliaj \& Hoogmoed, 1987). An additional advantage of this land treatment is that it facilitates interrow cultivation between ridges using animal traction.

Despite the advantages offered by tillage, it is important to recognize that when the soil is dry, tillage may create a loose top layer thus increasing its susceptibility to wind erosion. On the other hand, tillage under moist soil conditions gives more stable aggregates (Hoogmoed \& Klaij, 1989).

Use of a Limited Quantity of Fertilizer to Sustain Productivity and Increase the Water-use efficiency (WUE). Lack of P constitutes a major constraint to crop growth in the Sahel (Jones \& Wild, 1975). Results of studies conducted at ISC by the International Fertilizer Development Center (IFDC) showed that application of as little as $20 \mathrm{~kg}$ of $\mathrm{P}_{2} \mathrm{O}_{5}$ doubled the millet yields (Bationo et al., 1987). An important consequence of the use of fertilizer is increased WUE (Sivakumar, 1987).

Millet in the Sahel is traditionally grown in wide rows. Recent investigations at ISC, in collaboration with the Institute of Hydrology (Wallace et al., 1988), showed that water losses in such a system through soil evaporation could be a significant component of the total evapotranspiration (ET). 
One of the effective means of reducing evaporative losses is through the use of mulching or crop residues. Recent results from ISC (Bationo et al., 1987) showed that crop residues also help reduce the $\mathrm{Al}$ and $\mathrm{H}$ saturation of the exchange complex, a major problem on the sandy soils.

Use of Improved Crop Strategies. In view of the rainfall variability in the Sahel, early maturing cultivars have a better chance of success in most of the years. Our studies on drought spells showed that millet cultivars that mature in 90 to $95 \mathrm{~d}$ are more likely to avoid the long dry spells during the grain-filling phase than the long duration cultivars of millet that mature in $110 \mathrm{~d}$.

Research at ISC showed that intercropping of millet/cowpea is a useful cropping system. By manipulation of one or more agronomic components such as plant density, spacing etc., substantial yield increases in the intercropping systems can be achieved.

In years with early onset of rains, a complementary system to intercropping is the relay cropping of millet with cowpea for hay. In a field test at ISC, Sivakumar (1990b) showed that with early onset of rains, it is possible to establish a second crop of cowpea for hay. Cowpea enables effective use of the September rains, a large part of which would otherwise have been lost through evaporation because of the poor water-holding capacity of the soils at ISC and provides valuable hay (and possibly grain if rains continue into October) to the farmer.

\section{Synergistic Effects of Different Components}

Strategies for exploitation of soil and climatic resources discussed above demonstrate their value, but there is early evidence from the integrated operational scale research (OPSCAR) at ISC that a combination of these inputs offers much greater advantages, while sustaining the yields (ICRISAT, 1989). Field studies conducted at ISC from 1986 to 1988 evaluated the relative advantages offered by one or more combinations of fertilizer, improved varieties of millet and cowpea, animal traction for land preparation and weeding, and rotation of millet with cowpea. From the point of sustainable agriculture, the effect of rotation was most striking in comparison to other inputs such as improved variety along with fertilizer and animal traction. While inputs such as use of an improved millet variety and addition of $13 \mathrm{~kg}$ of $\mathrm{P} / \mathrm{ha}$ gave a $78 \%$ yield advantage over the traditional practice, the addition of a rotation treatment in the system boosted the yield advantage to $244 \%$ for the millet grain and $95 \%$ for the millet straw. These data demonstrate the value of effective soil and water management on the poor, sandy soils.

\section{Deep Vertisols of India and Africa}

Vertisols are dark-colored clayey soils that are found under varied climatic conditions covering about 310 million ha worldwide (Dudal, 1965). In Asia they cover much of India ( $70 \mathrm{~m} \mathrm{ha}$ ) and parts of Burma and Thailand. Several countries in Africa and Latin America have Vertisols and soils of 
vertic properties. In the tropical countries, these soils present serious problems of land and water management for increased productivity. During the dry season, these soils crack-cracks may be 5 to $20 \mathrm{~cm}$ in width and 30 to 50 $\mathrm{cm}$ in depth. Therefore, preparation of seedbed is difficult until the onset of the rainy season. Once the rainy season sets in, these soils present traffic problems for land preparation. It is difficult to maintain their surface configuration and since their terminal infiltration rates are extremely low, waterlogging during the rainy season is common.

Due to the constraints previously described, a popular myth prevailed in India that Vertisols cannot be cropped in the rainy season and the prevailing practice has been to leave the soils fallow in the rainy season and crop them in the postrainy season. Hence, the productivity of these soils remained generally low, for example, in the Deccan plateau of India average sorghum [Sorghum bicolor (L.) Moench] yield is about $700 \mathrm{~kg} / \mathrm{ha}$.

Vertisols of the semiarid tropics, however, have a fairly high potential for crop production that remains to be realized. The case study of Vertisols is illustrated primarily from the studies conducted at the ICRISAT Center located in Patancheru, near Hyderabad, India. This case study shows that through an understanding of climate and the application of science and technology of land, water, and crop management, Vertisols can be cropped in the rainy season and can be made productive.

\section{Land and Water Management}

Improved land and water management practices are applied for alleviating the constraints, such as waterlogging, which arise due to the physical properties of Vertisols. Vertisols have very poor internal drainage when they are wet. Under the improved system of management, microwatersheds of 3 to 15 ha size were taken as units for land and water management and agronomic practices. Surface drainage is improved through the provision of surface drains and land smoothing. The in-situ water conservation improvements are brought about by laying out the bed-furrow (ridge-furrow) cultivation systems along the contour. Since the surface runoff water is discharged in a controlled manner, the loss of soil is considerably reduced and WUE is increased considerably. At the ICRISAT Center, the main features of this system are that on a slope of 0.4 to $0.6 \%$ graded broadbeds and furrows (50-cm apart) are made that lead into grassed waterways and finally into a dug tank or drain. By following this system, the soil moisture storage is increased and the drainage of excess water is facilitated.

Primary tillage to prepare a rough seedbed is best carried out soon after the harvest of the postrainy- or rainy-season crops. Land should be harrowed whenever 20 to $25 \mathrm{~mm}$ of rain is received over a period of $1-2 \mathrm{~d}$. When blade harrowing is done, the clods easily shatter and a satisfactory seedbed is attained. 


\section{Dry Sowing Ahead of Onset of Rainy Season}

Since the preparation of the seedbed and the sowing of crops present serious problems in Vertisols, the planting of crops in dry soils ahead of the commencement of rains was found to ensure early establishment, and avoid the difficultues associated with planting in a wet, sticky soil. Dry seeding was found successful where the early season rainfall is fairly dependable and when seeds are placed at a depth of 7 to $10 \mathrm{~cm}$. At the ICRISAT Center, good stands were established by dry seeding of crops such as green gram [Vigna radiata (L.) R. Wilczek], sunflower (Helianthus annuus L.), maize, sorghum, and pigeonpea.

\section{Improved Cropping Systems}

The adoption of improved cropping systems provides a continuum of crop growth from the commencement of the rainy season until most of the available moisture is used by the crop. At ICRISAT this was achieved by:

1. Intercropping of long-duration crops (e.g., pigeonpea) with shortduration crops (e.g., maize, sorghum, or soybean).

2. Sequential cropping of crops (e.g., sorghum or maize followed by chickpea or safflower).

\section{Fertility Management}

In the tropics, the management of soil fertility is important for realizing the full potential of improved cropping systems. At the ICRISAT Center, effective management of soil and fertilizer $\mathrm{N}$ was found to be a necessary ingredient for improved productivity of Vertisols. Application of phosphates and $\mathrm{Zn}$ was also found to be essential. Inclusion of legumes in the crop rotations or in intercrop systems was found to have substantially reduced the fertilizer $\mathrm{N}$ needs (by about $40 \mathrm{~kg}$ of $\mathrm{N} / \mathrm{ha}$ ) of the subsequent cereal crops.

\section{Efficient Farm Machinery}

For a successful implementation of the improved Vertisols management system, it is necessary to carry out all the operations thoroughly and in good time. Since animal draught is the main source of energy available to small farm operators of semiarid areas in Asia and Africa, much of ICRISAT's work is related to animal-drawn equipment. Use of a wheeled tool carrier (e.g., Tropicultor or Nikart) was found to be an efficient technique for managing Vertisols in India.

\section{Appropriate Crop Management}

To realize the full potential of improved land and water management and cropping systems, it is essential that an appropriate set of crop management practices be adopted. Weed control, integrated pest management, the placement of fertilizers at an appropriate depth and their application at crit- 
Table 6-4.Grain yields under improved and traditional technologies on deep Vertisols $\dagger$ at ICRISAT Center $\ddagger$ in 13 successive yr.

Grain yield, t/ha

\begin{tabular}{|c|c|c|c|c|c|c|}
\hline \multirow[b]{3}{*}{ Year } & \multirow{3}{*}{$\begin{array}{l}\text { Cropping } \\
\text { period } \\
\text { rainfall, } \\
\text { mm }\end{array}$} & \multicolumn{3}{|c|}{ Improved system: Double cropping } & & \\
\hline & & \multirow{2}{*}{$\begin{array}{l}\text { Sorghum/ } \\
\text { Maize }\end{array}$} & \multirow{2}{*}{$\begin{array}{c}\text { Sequential } \\
\text { or chickpea } \\
\text { intercropped } \\
\text { pigeonpea }\end{array}$} & \multirow[b]{2}{*}{ Total } & \multicolumn{2}{|c|}{$\begin{array}{l}\text { Traditional system, } \\
\text { Single crop }\end{array}$} \\
\hline & & & & & Sorghum & chickpea \\
\hline $1976 / 77$ & 708 & 3.20 & 0.72 & 3.92 & 0.44 & 0.54 \\
\hline $1977 / 78$ & 616 & 3.08 & 1.22 & 4.30 & 0.38 & 0.87 \\
\hline $1978 / 79$ & 1089 & 2.15 & 1.26 & 3.41 & 0.56 & 0.53 \\
\hline $1979 / 80$ & 715 & 2.30 & 1.20 & 3.50 & 0.50 & 0.45 \\
\hline $1980 / 81$ & 715 & 3.59 & 0.92 & 4.51 & 0.60 & 0.56 \\
\hline $1981 / 82$ & 1073 & 3.19 & 1.05 & 4.24 & 0.64 & 1.05 \\
\hline $1982 / 83$ & 667 & 3.27 & 1.10 & 4.37 & 0.63 & 1.24 \\
\hline $1983 / 84$ & 1045 & 3.05 & 1.77 & 4.82 & 0.84 & 0.48 \\
\hline $1984 / 85$ & 546 & 3.36 & 1.01 & 4.37 & 0.69 & 1.23 \\
\hline $1985 / 86$ & 477 & 2.70 & 0.73 & 3.43 & $\S$ & 0.84 \\
\hline $1986 / 87$ & 585 & 4.45 & 0.38 & 4.83 & 0.37 & 1.27 \\
\hline $1987 / 88$ & 841 & 4.26 & 1.35 & 5.61 & 0.80 & 0.92 \\
\hline $1988 / 89$ & 907 & 4.64 & 1.23 & 5.87 & 0.61 & 1.18 \\
\hline Mean & 771 & 3.33 & 1.07 & 4.40 & 0.59 & 0.86 \\
\hline SD & 205 & 0.76 & 0.34 & 0.76 & 0.15 & 0.32 \\
\hline $\mathrm{CV}, \%$ & 27 & 23 & 32 & 17 & 25 & 37 \\
\hline
\end{tabular}

$\dagger$ Available water-holding capacity $150 \mathrm{~cm}$ per $\mathrm{m}$ of soil depth.

$\ddagger$ Average rainfall for Hyderabad (29 km away from ICRISAT Center) based on 1901-1984 data is $784 \mathrm{~mm}$ with a CV of $27 \%$.

$\S$ No crop sown.

ical stages of crop growth are some of the crop management factors that could lead to the realization of high and sustained yields on Vertisols.

One important aspect of the improved Vertisol technology is the synergistic effect of various components when applied together, as compared with their individual effect. This point has been brought out convincingly after $13 \mathrm{yr}$ of watershed-based experimental results from ICRISAT (Table 6-4). Kanwar and Rego (1983) and Kanwar et al. (1982) noted during the steps taken to improve Vertisols technology conducted at ICRISAT that though the contribution of fertilizers was highest, the response to fertilizers was most highly marked when they were applied in combination with improved land and water management treatments and the adoption of improved agronomic practices. This observation has great relevance in the African continent. Here fertilizers are costly and in most instances have to be imported. All efforts, therefore, must be made to realize maximum fertilizer-use efficiency by applying the principles of improved Vertisol technology.

\section{Improved Productivity}

Use of the above components of technology made it possible to grow two crops, one in the rainy season and another in the postrainy season and resulted in considerable increases in crop production (Virmani et al., 1989). Where a farmer harvested about one-half ton of sorghum or chickpea by 
Table 6-5. Grain yields of some cropping systems on vertic soils $\nmid$ under low (0-0-0) and medium (60-12-0) fertility at ICRISAT Center in operational scale experiments. Source: ICRISAT $(1983,1984)$.

\begin{tabular}{|c|c|c|c|c|c|c|c|}
\hline \multirow[b]{2}{*}{ Year } & \multirow{2}{*}{$\begin{array}{l}\text { Cropping } \\
\text { period } \\
\text { rainfall, } \\
\mathrm{mm}\end{array}$} & \multirow[b]{2}{*}{$\begin{array}{c}\text { Soil } \\
\text { fertility }\end{array}$} & \multicolumn{5}{|c|}{ Grain yield, $\mathrm{kg} / \mathrm{ha}$} \\
\hline & & & $\begin{array}{c}\text { Sole } \\
\text { pigeonpea }\end{array}$ & $\begin{array}{l}\text { Sorghum/ } \\
\text { pigeonpea }\end{array}$ & $\begin{array}{c}\text { Millet/ } \\
\text { pigeonpea }\end{array}$ & $\begin{array}{c}\text { Ground- } \\
\text { nut/ } \\
\text { pigeonpea }\end{array}$ & $\begin{array}{c}\text { Sole } \\
\text { sorghum }\end{array}$ \\
\hline \multirow[t]{2}{*}{$1981 / 82$} & 1073 & Low & 700 & 937 & 1201 & 1387 & 516 \\
\hline & & Medium & 868 & 2175 & 3581 & 1423 & 3234 \\
\hline \multirow[t]{2}{*}{$198 / 83$} & 667 & Low & 1041 & 2219 & 2190 & 2214 & 1170 \\
\hline & & Medium & 1217 & 4291 & 3178 & 2917 & 2869 \\
\hline
\end{tabular}

$\dagger$ Available water-holding capacity of $50 \mathrm{~cm}$ soil profile is $80 \mathrm{~mm}$.

using his traditional system, a total yield of about $3 \mathrm{t}$ of grain/ha has been consistently harvested through a two-crop combination under the improved Vertisols management system at ICRISAT during 1976-1989 (Table 6-4). Further, in the vertic soils several intercrop combinations (e.g., sorghumpigeonpea or millet-pigeonpea) have produced yields of 2 to $3 \mathrm{t} /$ ha under medium fertility treatment (60-12-0), as shown in Table 6-5. The introduction of the new system also has resulted in: (i) a considerable reduction in soil erosion; (ii) a much higher in-situ moisture conservation, and therefore in higher rainfall-use efficiency (Table 6-6); and (iii) much more dependable harvests year after year (Table 6-4).

Table 6-6. Annual water balance and soil loss ( $\mathrm{t} / \mathrm{ha}$ ) for traditional and improved technologies in Vertisol watersheds, ICRISAT Center, 1976-77 to 1983-84.

\begin{tabular}{|c|c|c|c|c|c|}
\hline \multirow[b]{2}{*}{$\begin{array}{l}\text { Farming systems } \\
\text { technology }\end{array}$} & \multicolumn{4}{|c|}{ Water-balance component } & \multirow[b]{2}{*}{ Soil loss } \\
\hline & $\begin{array}{l}\text { Annual } \\
\text { rainfall }\end{array}$ & $\begin{array}{l}\text { Water used } \\
\text { by crops }\end{array}$ & $\begin{array}{l}\text { Water lost } \\
\text { as surface } \\
\text { runoff }\end{array}$ & $\begin{array}{l}\text { Water lost } \\
\text { as bare soil } \\
\text { evaporation } \\
\text { and deep } \\
\text { percolation }\end{array}$ & \\
\hline \multicolumn{6}{|c|}{$-\mathrm{mm}$} \\
\hline \multicolumn{6}{|c|}{ Improved system: } \\
\hline $\begin{array}{l}\text { Double cropping on } \\
\text { broadbed and furrows }\end{array}$ & 904 & $602(67) \dagger$ & $130(14)$ & $172(19)$ & 1.5 \\
\hline \multicolumn{6}{|c|}{ Traditional system: } \\
\hline $\begin{array}{l}\text { Single crop in postrainy } \\
\text { season and cultivation } \\
\text { on flat }\end{array}$ & 904 & $271(30)$ & $227(25)$ & $406(45)$ & 6.4 \\
\hline
\end{tabular}

$\dagger$ Figures in parentheses are amounts of water used or lost expressed as percentage of total rainfall. 


\section{CONCLUSIONS}

In this chapter, we have attempted to show the important relationships between climate and soil productivity in the tropics. It is apparent that factors such as rainfall pattern, rainfall intensities and erosion, waterlogging, potential ET, length of the growing season, temperature, and wind should be carefully considered in an assessment of soil productivity in the tropics. Several myths concerning the role of these climatic factors exist and we tried to clarify relevant issues using data from current literature.

The case studies from research carried out at the ICRISAT Sahelian Center in Niger and at the ICRISAT Center in India show that productivity of tropical soils can be much improved by the application of improved understanding of climatic constraints to develop effective soil and watermanagement practices. Sustainability of tropical agriculture in the future is linked to our ability to understand the limits imported by environmental constraints on soil productivity and appropriately manage these soils while ensuring long-term stability.

\section{REFERENCES}

Balba, A.M. 1980. Desertification in North Africa. p. 14-25. In Desertification and soils policy. Symposia Papers III. 12th Int. Congr. Soil Sci., New Delhi, India.

Bationo, A., C.B. Christianson, and A. Mokwunye. 1987. Soil fertility management of the millet producing sandy soils of Sahelian West Africa: The Niger experience. p. 159-168. In Soil, crop and water management systems for rainfed agriculture in the Sudano-Sahelian zone: Proc. of an Int. Workshop. 11-16 Jan. ICRISAT Sahelian Center, Niamey, Niger. ICRISAT, Patancheru, India.

Bowden, L. 1979. Development of present dryland farming systems. p. 45-72. In A.E. Hall et al. (ed.) Agriculture in semi-arid environments. Springer-Verlag, Berlin.

Brengle, K.G. 1982. Principles and practices of dryland farming. Colorado Assoc. Univ. Press, Boulder.

Bridges, E.M. 1978. World soils. Cambridge Univ. Press, London.

Cannell, G.H., and L.V. Weeks. 1979. Erosion and its control in semi-arid regions. p. 238-256. In A.E. Hall et al. (ed.) Agriculture in semi-arid environments. Springer-Verlag, Berlin.

Charreau, C. 1972. Problemes poses par l'utilization agricole des soils tropicaux par des cultures annuelles. Trop. Soil Res. Symp. May 1972. Int. Inst. Trop. Agric. (IITA), Ibadan, Nigeria.

Charreau, C. 1974. Soils of tropical dry and dry wet climatic areas and their use and management. A series of lectures, Cornell Univ., Ithaca, NY.

Charreau, C., and R. Nicou. 1971. L'amélioration du profil cultural dans les sols sableux et sablo argileux de la zone tropicale séche Ouest Africaine et ses incidences agronomiques. Agric. Trop. 26 (2):209-225, (5):565-631, (9):903-978, 1183-1247.

Charreau, C., and L. Seguy. 1969. Measure de l'erosion et du ruissellement a Sefa en 1968. Agric. Trop. 20:6-7, 600-625.

Chepil, W.S., and N.P. Woodruff. 1963. The physics of wind erosion and its control. Adv. Agron. 15:211.

Cheverry, C. 1974. Contribution a l'étude pédologique des polders du lac Tchad. Mém. ORSTOM, Paris.

Constantinesco, I. 1976. Soil conservation for developing countries. FAO Soils Bull. 30. FAO, Rome.

Davy, E.G., F. Mattei, and S.I. Solomon. 1976. An evaluation of climate and water resources for development of agriculture in the Sudano-Sahelian zone of West Africa. Spec. Environ. Rep. 9. World Meterological Organization (WMO), Geneva, Switzerland. 
de Martonne, E. 1926. Une nouvelle fonction climatologique: L'indice d'aridite. La Météorol. 68:449-458.

Denmead, O.T., and R.H. Shaw. 1962. Availability of water to plants as affected by soil moisture content and meteorological conditions. Agron. J. 54:385-390.

Downes, J.D., D.W. Fryrear, R.L. Wilson, and C.M. Sabota. 1977. Influence of wind erosion on growing plants. Trans. ASAE 20:885.

Dudal, R. 1965. Dark clay soils of tropical and subtropical regions. Agric. Development Paper 83. FAO, Rome.

Edwards, K.A., and J.R. Blackie. 1975. Hydrological research in East Africa. E.A. Agric. For. J. (special issue).

Emberger, L. 1955. Une classification biogéographique des climats. Recueil des travaux des laboratoires des botanique, géologie et zoologie de la Faculté des Sciences de l'Université de Montpellier (Ser. Bot. No. 7):3-45.

Food and Agriculture Organization. 1977a. The FAO/UNFPA Expert Consultation on Land Resources for Population of the Future. FAO, Rome.

Food and Agriculture Organization. 1977b. A framework for land evaluation. FAO Soils Bull. 32 and ILRI Publ. 22. FAO, Rome, and ILRI, Wageningen.

Food and Agriculture Organization. 1977c. Assessing soil degradation. Soils Bull. 34. FAO, Rome.

Finkel, H.J. 1986a. Semiarid soil and water conservation. CRC Press, Boca Raton, FL.

Finkel, H.J. 1986b. Wind erosion. p. 109-121. In H.J. Finkel (ed.) Semiarid soil and water conservation. CRC Press, Boca Raton, FL.

Forest, F., and B. Lidon. 1984. Influence du regime pluviométrique sur la fluctuation du rendement d'une culture de sorgho intensifiée. p. 247-261. In Agrometeorology of sorghum and millet in the semi-arid tropics: Proc. Int. Symp. 15-20 Nov. 1982. ICRISAT Center, Patancheru, India.

Gavaud, M. 1968. Les sols bien draines sur materiaux sableux du Niger. Cah. Orstom, Ser. Pedol. 6:277-307.

Greenland, D.J. 1977. Soil structure and erosion hazard. In D.J. Greenland and R. Lal (ed.) Soil conservation and management in the humid tropics. John Wiley and Sons, New York.

Hargreaves, G.H. 1971. Precipitation dependability and potential for agricultural production in Northeast Brazil. Publ. 74-D159. EMBRAPA and Utah State Univ., Logan.

Holmes, R.M. 1961. Estimation of soil moisture content using evaporation data. In Proc. Hydrology Symp. 2. Evaporation. Dep. of Northern Affairs and Natural Resources, Water Resources Branch, Toronto, ON.

Hoogmoed, W.B. 1981. Analysis of rainfall in some locations of West Africa and India. In E. Rawitz et al. (ed.) Development of criteria and methods for improving the efficiency of soil management and tillage operations with special reference to arid and semi-arid regions. Tillage Lab., Agric. Univ., Wageningen, Netherlands and Dep. of Soils and Water Science, Hebrew Univ., Rehovot, Israel. Appendix 5.

Hoogmoed, W.B. 1986. Analysis of rainfall data relating to the number of days available for tillage and planting in some selected locations in Niger. Rep. 86-4. Agric. Univ., Wageningen, Netherlands and ICRISAT Sahelian Center, Niamey, Niger.

Hoogmoed, W.B., and M.C. Klaij. 1990. Soil management for crop production in the Sahel. I. Soil and climatic parameters. Soil Tillage Res. 16:85-103.

Hogomoed, W.B., and L. Stroosnijder. 1984. Crust formation on sandy soils in the Sahel. I. Rainfall and infiltration. Soil Teillage Res. 4:5-23.

International Crops Research Institute for the Semi-Arid Tropics. 1983, 1984. Annual Rep. 1983, 1984. ICRISAT, Patancheru, India.

International Crops Research Institute for the Semi-Arid Tropics. 1989. Annual report 1988. ICRISAT, Patancheru, India.

Jackson, I.J. 1977. Climate, water and agriculture in the tropics. Longman, London.

Jenkinson, D.S., and A. Ayanaba. 1977. Decomposition of carbon-14 labeled plant material under tropical conditions. J. Soil Sci. Soc. Am. 41:912-915.

Jones, M.J. 1973. The organic matter content of savanna soils of West Africa. J. Soil Sci. 24:42-53.

Jones, M.J., and A. Wild. 1975. Soils of the West African Savanna: The maintenance and improvement of their fertility. Tech. Commun. 55, Commonwealth Agricultural Bureaux, Farnham Royal, UK.

Kadeba, O. 1970. Organic matter and nitrogen status of some soils from the savanna zone of Nigeria. Proc. Inaugural Conf. Forestry Assoc., Nigeria, Ibadan. 
Kanwar, J.S., J. Kampen, and S.M. Virmani. 1982. Management of Vertisols for maximising crop production-ICRISAT Experience. p. 94-118. In Symposium Papers. II. Trans. Int. Soc. of Soil Sci. 12th. New Delhi, India. 8-16 Feb. Indian Soc. Soil Sci., New Delhi, India.

Kanwar, J.S., and T.J. Rego. 1983. Fertilizer use and watershed management in rainfed areas for increasing crop production. Fert. News 28:33-43.

Kelley, W.P. 1963. Use of saline irrigation water. Soil Sci. 95:385-391.

Klaij, M.C., and W. Hoogmoed. 1987. Crop response to tillage practices in a Sahelian soil. p. 265-276. In Workshop on Soil, Crop and Water Management Systems for Rainfed Agriculture in the Sudano-Sahelian Zone. 11-17 Jan. Niamey, Niger.

Klaij, M.C., and P.G. Serafini. 1988. Management options for intensifying millet based crop production systems on sandy soils in the Sahel. p. 501-503. In P.W. Unger et al. (ed.) Challenges in dryland agriculture. A global perspective. Proc. Int. Conf. on Dryland Farming. 15-19 Aug. Amarillo, Bushland, TX.

Koppen, W. 1931. Grundriss der Klimakunde. (Second ed. of Die Klimate der Erde). Springer Verlag, Berlin.

Koppen, W. 1936. Das geographische System der Klimate. In W. Koppen and R. Geiger (ed.) Handbuch der Klimatologie. Vol. 1, Part C. Gebruder Borntrager, Berlin.

Kowal, J.M. 1970. The hydrology of a small catchment basin at Samaru, Nigeria: Assessment of surface run-off under varied land management and vegetation. Niger. Agric. J. 7:120-133.

Kowal, J.M., and A.H. Kassam. 1977. Energy load and instantaneous intensity of rainstorms at Samaru, Northern Nigeria. In D.J. Greenland and R. Lal (ed.) Soil conservation and management in the humid tropics. John Wiley and Sons, New York.

Kowal, J.M., and A.H. Kassam. 1978. Agricultural ecology of savanna: A case study of West Africa. Clarendon Press, Oxford.

Kowal, J.M., and K.S. Stockinger. 1973. The usefulness of ridge cultivation in agriculture. Soil Water Conserv. J. 28:136-137.

Lal, R. 1974. Effect of constant and fluctuating soil temperatures on growth, development and nutrient uptake by maize seedlings. Plant Soil 40:586-606.

Lal, R. 1976a. Soil erosion investigations on an Alfisol in Southern Nigeria. IITA Monogr. I. Int. Inst. for Trop. Agric., Ibadan, Nigeria.

Lal, R. 1976b. Soil erosion on Alfisols in Western Nigeria. I: Effect of slope, rotation and residue management. Geoderma 16:363-375.

Lal, R. 1977. Analysis of factors affecting rainfall erosivity and soil erodibility. p. 49-55. In D.J. Greenland and R. Lal (ed.) Soil conservation and management in the humid tropics. John Wiley and Sons, New York.

Lal, R. 1980. Soil erosion as a constraint to crop production. p. 405-423. In Priorities for alleviating soil-related constraints to food production in the tropics. Int. Rice Res. Inst., Los Baños, Philippines.

Lal, R. 1981. Soil erosion problems on Alfisols in western Nigeria. VI. Effects of erosion on experimental plots. Geoderma 25:215-230.

Lal, R. 1987. Effects of soil erosion on crop productivity. CRC Crit. Rev. Plant Sci. 5:303-308.

Lal, R., T.L. Lawson, and A.H. Anastase. 1980. Erosivity of tropical rains. p. 143-151. In M. Deboodt and D. Gabriels (ed.) Assessment of erosion. John Wiley and Sons, Chichester, England.

Lawson, T.C., and M.V.K. Sivakumar. 1989. Climatic constraints to crop production and fertilizer use. Fert. Res. 29:9-21.

Lowe, R.G. 1974. Shifting cultivation and soil conservation in Africa. FAO Soils Bull. 24. FAO, Rome.

Lyles, L., L.A. Disrud, and N.P. Woodruff. 1969. Effect of soil physical properties, rainfall characteristics and wind velocity on clod disintegration by simulated rainfall. Proc. Soil Sci. Soc. Am. 33:302-306.

McIntyre, D.S. 1958. Permeability measurements of soil crusts formed by raindrop impact. Soil Sci. 85:185-189.

Miller, A.A. 1971. Climatology. Mathuen, London.

Perrier, E.A. 1987. An evaluation of soil-water management on an Alfisol in the semi-arid tropics of Burkina Faso. p. 59-66. In Alfisols in the semi-arid tropics. Proc. Consultants Workshop on the State of the Art and Management Alternatives for optimizing productivity of SAT Alfisols and related soils. 1-3 Dec. 1983. ICRISAT, Patancheru, India.

Pfordresher, A., L.P. Wilding, L.R. Hossner, A. Manu, S.C. Geiger, and R.C. Maggio. 1989. Applications of infrared video imagery to evaluate crop spatial variability in the Sahel, West Africa. Dep. of Soil and Crop Sciences/TROPSOILS, Texas A\&M Univ., College Station. 
Roose, E.J. 1973. Dix-sept années de mesures expérimentales de l'erosion et du ruissellment sur un sol ferrallitique sableux de basse Cote d'Ivoire. Contribution a l'étude de l'erosion hydrique en milieu intertropical. ORSTOM, Abidjan, Thése Doct. Ing., Fac. Sci. Abidjan.

Roose, E.J. 1977. Application of the universal soil loss equation of Wischmeier and Smith in West Africa. p. 177-187. In D.J. Greenland and R. Lal (ed.) Soil conservation and management in the humid tropics. John Wiley and Sons, New York.

Roose, E.J., and R. Bertrand. 1971. Contribution a l'etude de la méthode des bandes d'arret pour lutter contre l'erosion hydrique en Afrique de l'ouest. Résultats expérimentaux et observations sur le terrain. Agron. Trop. (Paris) 26:1270-1283.

Roose, E.J., and Y. Birot. 1970. Mesure de l'erosion et du lessionage oblique et vertical sous une savane arbor e du plateau Mossi (Gonse, Haute-Volta Campagnes 1968-69) CIFT.1 ORSTOM. Inst. Francais de Recherche Sci. pour le Developpement en Coop., Paris.

Russell, M.B. 19080. Profile moisture dynamics of soil in Vertisols and Alfisols. p. 75-87. In Proc. Int. Workshop on the Agriclimatological Res. Needs of the Semi-Arid Tropics. 22-24 Nov. 1978. ICRISAT, Patancheru, India.

Sivakumar, M.V.K. 1987. Agroclimatic aspects of rainfed agriculture in the Sudano-Sahelian zone. p. 17-38. In Workshop on Soil, Crop and Water Management Systems for Rainfed Agriculture in the Sudano-Sahelian Zone. 11-17 Jan. Niamey, Niger.

Sivakumar, M.V.K. 1988. Predicting rainy season potential from the onset of rains in the Sahelian and Sudanian climatic zones of West Africa. Agric. Forest Meteorol. 42:295-305.

Sivakumar, M.V.K. 1990. Exploiting rainy season potential from the onset of rains in the Southern Sahelian zone of West Africa. Agric. Forest Meteorol. 51:321-332.

Sivakumar, M.V.K. 1991. Drought spells and drought frequencies in West Africa. Res. Bull. 13. ICRISAT, Patancheru, India.

Sivakumar, M.V.K., and J.L. Hatfield. 1990. Spatial variability of rainfall on an experimental station in Niger, West Africa. Theo. Appl. Climat. 42:33-39.

Spencer, D.S.C., and M.V.K. Sivakumar. 1987. Pearl millet in African agriculture. p. 19-31. In Proc. Int. Pearl Millet Workshop. 7-11 Apr. 1986. ICRISAT, Patancheru, India.

Thornthwaite, C.W. 1948. An approach towards a rational classification of climate. Geogr. Rev. 38:55-94.

Trewartha, G.T. 1968. An introduction to climate. McGraw-Hill Book Co., New York.

Troll, C. 1965. Seasonal climates of the earth. p. 28. In E. Rodenwalt and H. Jusatz (ed.) World maps of climatology. Springer Verlag, Berlin.

Verne, R., and P. Williams. 1965. Résultats des études de l'erosion au Dahomey. Communication au Colloque: Conservation et amélioration de la fertilité des sols; Khartoum. Organ. Afr. Unity Sci. Tech. Res. Comm. Publ. 98:43-53.

Vine, H. 1949. Nigerian soils in relation to parent materials. Commonw. Bur. Soil Sci. Tech. Commun. 46:22-29.

Virmani, S.M. 1980. Climatic approach. p. 93-102. In Proc. Int. Symp. on Devel. and Transfer of Technology for Rainfed Agriculture and the SAT Farmer. 28 Aug.-1 Sept. 1979. ICRISAT, Patancheru, India.

Virmani, S.M., M.R. Rao, and K.L. Srivastava. 1989. Approaches to the management of Vertisols in the semi-arid tropics: The ICRISAT experience. p. 17-36. In Management of Vertisols for improved agricultural production: Proc. an IBSRAM Inaugural Workshop. 18-22 Feb. 1985. ICRISAT Center, Patancheru, India.

Wallace, J.S., J.H.C. Gash, D.D. McNeil, and M.V.K. Sivakumar. 1988. Measurement and prediction of actual evaporation from sparse dryland crops. Scientific Rep. on Phase II of ODA Proj. 149. Inst. Hydrology, Wallingford, UK.

Wendt, J. 1986. Pearl millet response to soil variability in sandy Ustalfs near Niamey, Niger, West Africa. M.Sc. thesis. Texas A\&M Univ., College Station.

Wischmeier, W.H., and D.D. Smith. 1958. Rainfall energy and its relationship to soil loss. Am. Geophys. Union 39:285-291.

Wischmeier, W.H., and D.D. Smith. 1960. A universal soil loss equation to guide conservation farm planning. Trnas. Int. Congr. Soil Sci., 7th 1:418-425.

World Meteorological Organization. 1983. Meteorological aspects of certain processes affecting soil degradation-especially erosion. Tech. Note 178. WMO, Genera.

Wortman, S., and R.W. Cummings, Jr. 1978. To feed this world: The challenge and the strategy. Johns Hopkins Univ. Press, Baltimore, MD. 